\title{
Light-chain nephropathy in patient with renal carcinoma
}

\author{
G ENIA, S MARINGHINI， A L'ABBATE, C ZOCCALI, Q MAGGIORE
}

\begin{abstract}
Paraneoplastic syndromes are often associated with renal parenchymal tumours. This report describes a case of renal-cell carcinoma with kappa-chain nephropathy. The patient, a 60-year-old man, had renal tubular dysfunction, shown by low serum concentrations of urate and phosphate. Kappa-chains were found in both serum and urine, but no lambda-chains were found. Investigations showed a clear-cell carcinoma, and the patient underwent a radical nephrectomy. Two years after operation serum phosphate and urate concentrations had returned to normal, and kappa-chains were undetectable in serum or urine.

The absence of lambda-chains indicates that the lightchain proteinuria was due to overproduction of the $M$ component, and the disappearance of kappa-chains after the operation suggests a causal relation between the renal tumour and the overproduction of the $M$ component.
\end{abstract}

\section{Introduction}

Several types of paraneoplastic syndrome in association with renal parenchymal tumours have been described. We here report an unusual case of renal-cell carcinoma associated with $x$-chain nephropathy.

\section{Case report}

A 60-year-old man was admitted in April 1976 complaining of fever, anorexia, and pronounced weakness, which had lasted for two months. From the age of 35 he had been moderately hypertensive. One month before admission laboratory examination showed a serum creatinine

\footnotetext{
Centro Fisiologia Clinica del Consiglio Nazionale delle Ricerche and Renal Unit, Reggio Calabria, Italy

G ENIA, MD, clinical assistant

S MARINGHINI, MD, clinical assistant

A L'ABBATE, MD, clinical assistant

C ZOCCALI, MD, clinical assistant

Q MAGGIORE, MD, director
}

concentration of $353 \mu \mathrm{mol} / 1(4 \mathrm{mg} / 100 \mathrm{ml})$, glycosuria, and slight proteinuria. On admission physical examination did not show abdominal masses or other pathological findings. Laboratory investigations showed hypouricacidaemia, hypophosphataemia, and a greatly reduced creatinine clearance (see table). Fractional excretion of urate

Course of light-chain nephropathy after removal of cancerous kidney in fune 1976

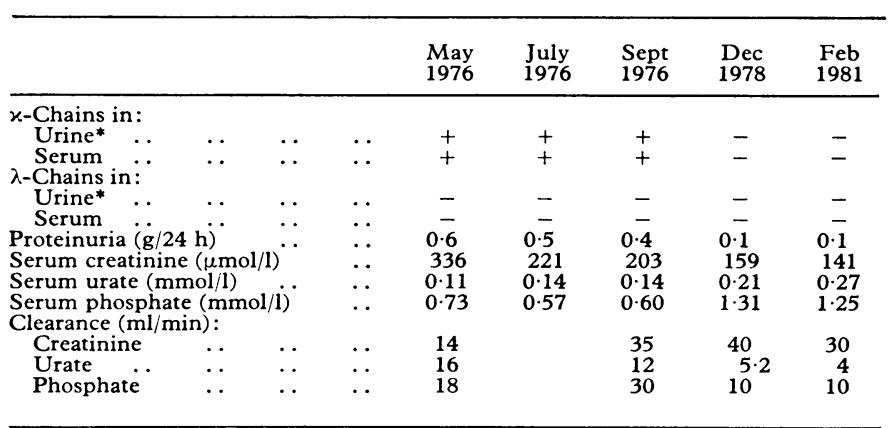

*Unconcentrated specimens.

Conversion: SI to traditional units-Serum creatinine: $1 \mu \mathrm{mol} / 1 \approx 0.01 \mathrm{mg} / \mathrm{dl}$ Serum urate: $1 \mathrm{mmol} / 1 \approx 16.8 \mathrm{mg} / \mathrm{dl}$. Serum phosphate: $1 \mathrm{mmol} / 1 \approx 3.1 \mathrm{mg} / \mathrm{dl}$.

was $114 \%$ and that of phosphate $128 \%$, which were considerably above the expected range for the patient's glomerular filtration rate. ${ }^{2}$ The erythrocyte sedimentation rate was $90 \mathrm{~mm}$ in the first hour, haemoglobin concentration $10 \mathrm{~g} / \mathrm{dl}$, and serum calcium concentration $2.2 \mathrm{mmol} / 1(9 \mathrm{mg} / 100 \mathrm{ml})$. Urinary sediment contained a few white cells and granular casts per high power field. Proteinuria was $0.6 \mathrm{~g} / 24$ $\mathrm{h}$; glycosuria, up to $6 \mathrm{~g} / \mathrm{l}$, was detected with a fasting plasma glucose concentration ranging from $4 \cdot 4$ to $7 \cdot 2 \mathrm{mmol} / 1$ ( 80 to $130 \mathrm{mg} / 100 \mathrm{ml})$. The urinary $\mathrm{pH}$ was $5 \cdot 5$, arterial blood $\mathrm{pH} 7 \cdot 33, \mathrm{HCO}_{3}$ concentration was $18 \mathrm{mmol}(\mathrm{mEq}) / 1$, and $\mathrm{PCO}_{2} 4.5 \mathrm{kPa}(34 \mathrm{~mm} \mathrm{Hg})$.

Urine cellogel electrophoresis (Chemetron, Milan) of unconcentrated specimens showed a single well-defined light-chain band and a trace amount of albumin. $x$-Chains were detected in both serum and urine by double immunodiffusion (Ouchterlony test); $\lambda$-chains were not found even in urine concentrated fiftyfold. Serum protein electrophoresis, $\operatorname{IgG}, \operatorname{IgA}, \operatorname{IgM}$, and $\mathrm{C}_{3}$ concentrations were normal. Two bone-marrow aspirates showed a normal cellular pattern.

The plain abdominal film showed an area of scattered, mottled calcifications over right mid-renal area. An intravenous pyelogram and a selective right renal arteriogram showed normal renal outlines and normal excretory cavities and vessels. Only on an arteriogram with 
adrenaline injection were a few abnormal vessels identified in the region of the calcification, which showed partial vasoconstriction. This doubtful finding and the unexplained renal parenchymal calcification prompted us to ask for an exploration of the right kidney. A radical nephrectomy was carried out because of a mass $4 \mathrm{~cm}$ in diameter suggestive of an hypernephroma confined to the middle portion of the kidney. Examination by light microscopy showed a clear-cell renal carcinoma. The unaffected renal tissue showed focal glomerular obsolescence and minor changes in the remaining glomeruli, tubular atrophy with intraluminal casts, interstitial fibrosis, and irregular hyaline thickening of arterioles. Special stainings for amyloid on renal tissue and on a surgical liver specimen were negative.

The changes that occurred after operation are depicted in the table. Three months after nephrectomy creatinine clearance had increased but the patient still had $x$-chains in his serum and urine as well as reduced concentrations of serum urate and phosphate. He was seen again two years later, when $x$-chains were no longer present either in urine or in serum and serum phosphate and urate concentrations had returned to normal values, with clearances and fractional excretions appropriate to the concurrent creatinine clearance. At the last study in February 1981, nearly five years after the operation, the patient appeared well. Arterial blood pressure was $170 / 100 \mathrm{~mm} \mathrm{Hg}$, and fasting plasma glucose concentration was $12.7 \mathrm{mmol} / 1(230 \mathrm{mg} / 100$ $\mathrm{ml}$ ). Light chains were still undetectable either in serum or in spot urine specimens; the tenfold concentrated urinary specimen contained both $x$-chains and $\lambda$-chains.

\section{Discussion}

Along with renal tubular dysfunction, manifested by low serum concentrations of urate and phosphate with clearances inappropriately high with respect to that of creatinine, this patient had $x$-chains in both serum and urine. $\lambda$-Chains were undetectable even in urine samples concentrated several folds. Hence the light-chain proteinuria was due to overproduction with overflow excretion of the $M$ component. A frequent association between monoclonal gammopathy and non-reticular cancers, especially of the colon and biliary tracts, has long been recognised. ${ }^{3}$ It has been suggested that tumoural antigens might cause stimulation of immunocytes or that the neoplastic cells themselves might produce the $\mathrm{M}$ component. ${ }^{3}$ Both monoclonal gammopathy and cancer, however, prevail in old age, and a chance association between them cannot be excluded. In our patient the disappearance of $x$-chains from serum after surgical treatment argues in favour of a causal relation between the renal tumour and the overproduction of the $M$ component.

Much experimental and clinical evidence shows that lightchain overproduction may induce renal tubular dysfunction. ${ }^{4}$ In this patient the improvement in tubular dysfunction after $x$-chains had disappeared from serum may be interpreted as evidence of light chains exerting a nephrotoxic effect.

Requests for reprints should be addressed to: Prof $\mathrm{Q}$ Maggiore, Centro di Fisiologia Clinica del CNR, Via Sbarre Inferiori 39, 89100 Reggio Calabria, Italy.

\section{References}

${ }^{1}$ Steele TH, Riesselbach RE. The contribution of residual nephrons within the chronically diseased kidney to urate homeostasis in man. $\mathrm{Am} \mathcal{F} \mathrm{Med}$ $1967 ; 43: 876$.

${ }^{2}$ Popovtzer MM, Shaineik H, Massry SG, Kleeman CR. Divalent ion excretion in chronic renal disease : relation to degree of renal insufficiency. Clin Sci 1970;38:297.

3 Waldenström JG. Benign monoclonal gammopathies. In: Azar HA, Potter M, eds. Multiple myeloma and related disorders. Vol 1. Hagerstown, Md: Harper and Row, 1973:247-86.

4 Smithline N, Kassirer JP, Cohen JJ. Light-chain nephropathy. N Engl f Med 1976:294:71-4

${ }^{5}$ Maldonado JE, Velosa JA, Kyle RA, Wagoner RD, Holley KE, Salassa RM. Fanconi syndrome in adults. $A m \mathcal{F} \operatorname{Med} 1975 ; 58: 354-64$.

(Accepted 11 fune 1981)

\title{
Oxytocin enhances onset of lactation among mothers delivering prematurely
}

\author{
H RUIS， R ROLLAND，W DOESBURG，G BROEDERS， R CORBEY
}

\begin{abstract}
In a double-blind group sequential trial the efficiency of an oxytocin nasal spray in enhancing lactation was studied during the first five days after delivery in women who had given birth prematurely. The cumulative volume of breast milk obtained between the second and fifth days after delivery was 3.5 times greater in primiparas given oxytocin than in primiparas given placebo.
\end{abstract}

Department of Obstetrics and Gynaecology, Groot Ziekengasthuis, 's-Hertogenbosch, the Netherlands

H RUIS, MD, registrar

G BROEDERS, MD, gynaecologist

R CORBEY, MD, gynaecologist

Department of Obstetrics and Gynaecology, Division of Gynaecologic Endocrinology and Infertility, University Hospital, Nijmegen, the Netherlands

R ROLLAND, MD, professor of gynaecology, endocrinology, and infertility

Department of Statistical Consultation, University, Nijmegen, the Netherlands

W DOESBURG, consulting statistician
There was no significant difference in the composition of the milk between the untreated women and those given oxytocin.

The results of this study show that oxytocin nasal spray is an effective and safe means of enhancing lactation in women using a breast pump.

\section{Introduction}

The feeding of premature infants has long been controversial among neonatologists. ${ }^{1}$ The protective properties of breast milk against sepsis $^{23}$ and necrotising enterocolitis ${ }^{45}$ are well recognised, and breast milk is more digestible than artificial milks. Workers are agreed on the desirability of using fresh milk for feeding premature infants when the donor is the infant's own mother. ${ }^{6}$ The idea that the protein content of human milk is low seems to have been refuted by Atkinson et $a l,^{7}$ who showed that the milk of mothers of premature infants has a higher nitrogen concentration than normal.

All clinical workers know that establishing sufficient lactation by using a breast pump or manual expression is difficult, especially in primiparas. ${ }^{8} 9$ There are three methods of improv- 